\begin{tabular}{|c|c|c|}
\hline \multirow[b]{2}{*}{ CEI I ENT } & Int.J.Curr.Microbiol.App.Sci (2021) 10(08): 736-744 & \\
\hline & $\begin{array}{l}\text { International Journal of Current Microbiology and Applied Sciences } \\
\text { ISSN: 2319-7706 Volume } \mathbf{1 0} \text { Number } 08 \mathbf{( 2 0 2 1 )} \\
\text { Journal homepage: } \underline{\text { http://www.ijcmas.com }}\end{array}$ & 09 \\
\hline PUBLISHERS & & www. ijcmas.com \\
\hline
\end{tabular}

Original Research Article

https://doi.org/10.20546/ijcmas.2021.1008.082

\title{
Perception of Zero Budget Natural Farming in Visakhapatnam District of Andhra Pradesh, India
}

\author{
Kuramdasu Vijaya Saradhi, Jahanara and Harihara Tripathy* \\ Department of Agricultural Extension and Communication, SHUATS, \\ Prayagraj, Uttar Pradesh, India \\ *Corresponding author
}

Keywords

ZBNF, Perception, natural farming, beneficiaries and non-beneficiaries

Article Info

Accepted:

25 July 2021

Available Online:

10 August 2021
Zero Budget Natural Farming (ZBNF) is a holistic alternative to the present paradigm of high-cost chemical inputs-based agriculture. Government of Andhra Pradesh (GoAP), Department of Agriculture (DoA) implemented Andhra Pradesh 'ZeroBudget' Natural Farming (APZBNF) Programme, through Rythu Sadhikara Samastha (RySS) (corporation for farmers' empowerment).RySS is a not -for-profit organization established by GoAp. The programme has been initiated in 2015-16 with multiple objectives of enhancing farmers' welfare, consumer welfare and for the conservation of the Farming (ZBNF). The present study was undertaken in Visakhapatnam District of Andhra Pradesh. Data was collected from 120 respondents including both Beneficiaries (60) and Non- Beneficiaries (60) using structured interview schedule. The findings of the study revealed that majority of the beneficiary farmers had High level of Perception (55.00\%), followed by both Medium (41.66\%) and Low $(3.33 \%)$ while in case of non-beneficiaries majority of the respondents had low level of perception (51.66\%) followed by medium (33.33\%) and low (51.66\%). constraints faced by the respondents were poor marketing facilities followed by Intensive labour requirement and low yield in initial years. The suggestions offered based on the study for overcoming the problems were providing marketing facilities and subsidies for purchasing the ZBNF inputs.

\section{Introduction}

After witnessing the harmful effects of chemical farming newly introduced agriculture technique among farmers is Zero Budget Natural farming (ZBNF) also known as Zero Budget Spiritual Farming (ZBSF). It has attained wide success in southern India; especially Karnataka where it was firstly evolved. Now it is spreading all over India, so rapidly and dynamically. The Govt. of Andhra Pradesh vision is to enhance short term and long term farmer's welfare, particularly small and marginal farmers, through climate change resilient, low cost Zero budget Natural Farming (ZBNF). The Government of Andhra Pradesh through Rythu Sadhikara Samastha launched ZBNF scaling- out initiative on 2nd 
June 2018 by Hon'ble Chief Minister Mr. Chandrababu Naidu. The study investigated farmers' perception on Zero Budget Natural Farming. Replacing fertilizers and pesticides with concoctions of locally available cow dung. Cow urine, jaggery and pulse flour, ZBNF ensures perfect soil conditions for plant growth while ensuring protection against pests $(1,2)$. Keeping this points stated above the present study was undertaken in Visakhapatnam district of Andhra Pradesh with the following objectives:

To access the socio-economic profile of the beneficiaries and non-beneficiaries.

To measure the perception level of ZBNF by the beneficiaries and non- beneficiaries farmers.

\section{Materials and Methods}

The study was conducted in Visakhapatnam District of Andhra Pradesh. Ex-post facto research design was used in the study. Ex-post research design is a method in which groups with qualities that already exist are compared on some dependent variable. It is also known as "after the fact" research, an ex post facto design is considered quasi-ex periment because the subjects are not randomly assigned-they are grouped based on a particular characteristic or trait. Andhra Pradesh state was selected purposively on the basis of maximum area under ZBNF practices. The Visakhapatnam District was selected purposively for research investigation because it consists of huge number of $\mathrm{ZBNF}$ cultivating in this area. There are about 47 mandals in Visakhapatnam district of Andhra Pradesh, out of which two mandals i.e., Payakarao Peta and Chodavaram mandals have been selected purposively on the basis of maximum area practicing under ZBNF. A complete list of all the villages were selected according to beneficiaries and non- beneficiaries in consultation with the help of District Agriculture office, District Project Manager of ZBNF, Rythu Barosa Kendras (RBK's), SD's, ICRP's and CRP'S of ZBNF programme. The primary data was collected with the help of personal interview technique with the help of interview schedule with especially objectives, focused study. Secondary data was collected from library, journals, books, pa pers, and other materials related to study. Data was analyzed using descriptive statistical tools like frequency, percentage. Karl Pearson's Co-efficient of Correlation test was applied to find out the association between perceptions with independent variables.

\section{Results and Discussion}

\section{From the table-1. The results depicted as followed}

Majority of the beneficiary respondents belonged to Middle Age group. This group alone constitutes 53.33 per cent of the total sample of 60 followed by 35.00 per cent of the respondents were illiterate, 46.67 per cent of the respondents belonged to high categories i.e. above 70,000 Annual Income, 78.33 per cent farmers possessed low amount of land holding (up to 3 acres), 61.66 per cent of respondents belonged to the low level of mass media exposure followed by 46.67 per cent of respondents belonged to the medium level of extension participation, 56.67 per cent of the respondents belonged to medium level of extension contacts, 68.33 per cent of respondents belonged to the medium level of risk orientation capacity and 53.33 per cent of the respondents belonged to the high level of scientific orientation capacity.

In case of non-beneficiary respondents Middle Age group. This group alone constitutes 71.66 per cent of the total sample of 60 followed by 45.00 per cent of the respondents were 
illiterate, 45.00 per cent of the respondents belonged to low categories i.e., 30,00050,000 Annual Income, 56.67 per cent farmers possessed low amount of land holding (up to 3 acres), 81.67 per cent of respondents belonged to the low level of mass media exposure followed by 90.00 per cent of respondents belonged to the medium level of extension participation, 63.33 per cent of the respondents belonged to low level of extension contacts, 51.67 per cent of respondents belonged to the medium level of risk orientation capacity and 66.67 per cent of the respondents belonged to the high level of scientific orientation capacity.

From the table-2. The results depicted as followed

The data presented in above table- 2 reveals that in case of beneficiary farmers 95.00 per cent of farmers agree with their statement that $\mathrm{ZBNF}$ is relatively advantageous over chemical farming followed by 76.66 per cent of farmers agree with their statement that ZBNF gives more net returns, 61.66 per cent of farmers are agree with their statement that ZBNF reduces cost of cultivation, 41.66 per cent of farmers are agree with their statement that $\mathrm{ZBNF}$ is feasible to adopt in present farming situation, 40.00 per cent of farmers are disagree agree with their given statement that ZBNF is complex to adopt, 96.66 per cent of farmers are agree with their given statement that ZBNF enriches the soil, 82.66 per cent of farmers are agree with their given statement that ZBNF gives sustainable yield, 86.67 per cent of farmers are agree with their given statement that ZBNF facilitates natural enemies population, 50.00 per cent of farmers are disagree with their given statement that ZBNF is difficult to practice, 91.66 per cent of farmers are agree with their statement that ZBNF produces quality production, 93.33 per cent of farmers are disagree with their given statement that ZBNF increases microorganisms and earthworms in soil, 45.00 per cent of farmers are disagree with their given statement that $\mathrm{ZBNF}$ is possible on large scale, 65.00 per cent of farmers are disagree with their given statement that preparation of asthras is difficult, 78.33 per cent of farmers are disagree with their given statement that weed management is difficult in ZBNF, 83.33 per cent of farmers agree with their given statement that availability of traditional varieties seed is difficult and 55.00 per cent of farmers agree with given statement that purchasing and maintaining of traditional cows is difficult.

The data presented in above table- 2 reveals that in case of non-beneficiary farmers 40.00 per cent of farmers undecided with their statement that $\mathrm{ZBNF}$ is relatively advantageous over chemical farming followed by 41.66 per cent of farmers undecided with their statement that ZBNF gives more net returns, 51.67 per cent of farmers are undecided with their statement that ZBNF reduces cost of cultivation, 43.33 per cent of farmers are disagree with their statement that ZBNF is feasible to adopt in present farming situation, 68.33 per cent of farmers are agree with their given statement that ZBNF is complex to adopt, 58.33 per cent of farmers undecided with their given statement that ZBNF enriches the soil, 70.00 per cent of farmers are undecided with their given statement that ZBNF gives sustainable yield, 68.33 per cent of farmers are agree with their given statement that ZBNF facilitates natural enemies population, 53.33 per cent of farmers are agree with their given statement that ZBNF is difficult to practice, 61.66 per cent of farmers are disagree with their statement that ZBNF produces quality production, 61.66 per cent of farmers are disagree with their given statement that ZBNF increases microorganisms and earthworms in soil, 58.33 per cent of farmers are disagree with their given statement that $\mathrm{ZBNF}$ is possible on 
large scale, 53.33 per cent of farmers are agree with their given statement that preparation of asthras is difficult, 60.00 per cent of farmers are agree with their given statement that weed management is difficult in ZBNF, 68.33 per cent of farmers agree with their given statement that availability of traditional varieties seed is difficult and 50.00 per cent of farmers agree with given statement that purchasing and maintaining of traditional cows is difficult.

From the table 3.The results depicted as followed

The data presented in above table reveals that majority of respondents belonged to the high level of perception level categories. This group alone consists 55 per cent of the total sample followed by 41.67 per cent were medium level and 3.33 per cent respondents were having low level of perception towards ZBNF.

\section{From the table 4.The results depicted as followed}

The data presented in above table reveals that majority of non-beneficiaries respondents belonged to the low level of perception level categories.

This group aloe constitutes 51.67 per cent of the total sample followed by 33.33 per cent were medium level and 15 per cent were having low level of perception towards ZBNF.

The above table- 4 indicates that, in case of beneficiary farmers, Mass Media Exposure, Extension Participation, Extension contacts, Risk orientation and scientific orientation had positive and highly significant relationship with perception of the respondents towards ZBNF at 0.01 level of probability. Family size, Education, Annual Income had negatively significant relationship with perception of the respondents towards ZBNF at 0.01 level of probability whereas Land Holding had positive and highly significant relationship with perception of the respondents towards $\mathrm{ZBNF}$ at 0.05 level of probability. Therefore, the null hypothesis (H0) framed for these variables were rejected.

While Age had no significant relationship with perception level of the respondents towards ZBNF.

In case of non-beneficiary Age, Education, family size, Annual income, Land holding, Mass Media Exposure, Extension participation, Extension contacts, Risk orientation and scientific orientation had positive and highly significant relationship with perception of the respondents towards ZBNF at 0.01 level of probability. Therefore, the null hypothesis (H0) framed for these variables were rejected. But in case of Age of the farmers had no significant relationship with perception level of the respondents towards ZBNF.

The socio-economic status of the respondents constitutes medium level in beneficiaries while in case of non-beneficiaries majority of the respondents had low level of socioeconomic profile.

It was revealed that majority of the Beneficiary farmers had high level of perception while in case of non-beneficiaries majority of the respondents had low level of perception (4-6).

Major suggestion offered based on the study for overcoming the problems were focus on non-availability of the ZBNF inputs and provide good market facilities for beneficiaries and in case of non-beneficiaries were pro per training should be given and timely advises should be provide regarding application \& preparation of asthras. 
Table.1 Socio-economic profile of the respondents

\begin{tabular}{|c|c|c|c|c|}
\hline \multirow[t]{2}{*}{ Sl.no. } & \multirow{2}{*}{\multicolumn{2}{|c|}{$\begin{array}{l}\text { Socio-economic profile of the beneficiary } \\
\text { respondents }\end{array}$}} & \multirow{2}{*}{$\begin{array}{c}\text { Beneficiaries } \\
\text { Frequency } \\
\end{array}$} & \multirow{2}{*}{$\begin{array}{c}\text { Non- } \\
\text { Beneficiaries } \\
\text { Frequency }\end{array}$} \\
\hline & & & & \\
\hline \multirow[t]{3}{*}{1.} & \multirow{3}{*}{ Age } & Low(20-35 years) & $16(26.67)$ & $04(6.66)$ \\
\hline & & Medium(36-55 years) & $32(53.33)$ & 43(71.67) \\
\hline & & High (above 55 years) & $12(20.00)$ & $13(21.67)$ \\
\hline \multirow[t]{5}{*}{2.} & \multirow[t]{5}{*}{ Education } & Illiterate & $21(35.00)$ & $27(45.00)$ \\
\hline & & Primary & $05(8.33)$ & $06(10.00)$ \\
\hline & & Up per Primary & $06(10.00)$ & $09(15.00)$ \\
\hline & & Secondary & $12(20.00)$ & 08(13.33) \\
\hline & & Gradate \& Above & $16(26.67)$ & $10(16.66)$ \\
\hline \multirow[t]{3}{*}{3.} & \multirow[t]{3}{*}{ Annual Income } & Low (up to Rs.30,000) & $18(30.00)$ & 27(45.00) \\
\hline & & Medium(Rs.50,000-70,000 & $14(23.33)$ & $21(35.00)$ \\
\hline & & High (Above Rs.70,000 ) & $28(46.67)$ & $12(20.00)$ \\
\hline \multirow[t]{3}{*}{4.} & \multirow[t]{3}{*}{ Land holding } & Low (0-3 Acres) & $47(78.33)$ & $34(56.66)$ \\
\hline & & Medium (3-5 Acres) & $04(6.67)$ & $22(36.67)$ \\
\hline & & High (Above 5 Acres) & $09(15.00)$ & $04(6.67)$ \\
\hline \multirow[t]{3}{*}{5.} & \multirow{3}{*}{$\begin{array}{l}\text { Mass media } \\
\text { Exposure }\end{array}$} & Low (4-7) & $37(61.67)$ & $49(81.67)$ \\
\hline & & Medium (8-10) & $12(20.00)$ & 07(11.66) \\
\hline & & $\operatorname{High}(11-13)$ & $11(18.33)$ & $04(6.67)$ \\
\hline \multirow[t]{3}{*}{6.} & \multirow{3}{*}{$\begin{array}{c}\text { Extension } \\
\text { Participation }\end{array}$} & Low (9-13) & $22(36.67)$ & $54(90.00)$ \\
\hline & & Medium(14-18) & $28(46.67)$ & $04(6.67)$ \\
\hline & & High $(19-25)$ & $10(16.66)$ & $02(03.33)$ \\
\hline \multirow[t]{3}{*}{7.} & \multirow{3}{*}{$\begin{array}{l}\text { Extension } \\
\text { Contacts }\end{array}$} & Low (5-8) & $08(13.33)$ & $38(63.33)$ \\
\hline & & Medium(9-11) & $34(56.67)$ & $16(26.67)$ \\
\hline & & $\operatorname{High}(12-15)$ & $18(30.00)$ & $06(10.00)$ \\
\hline \multirow[t]{3}{*}{8.} & \multirow[t]{3}{*}{ Risk orientation } & Low (10-12) & $10(16.67)$ & $14(23.33)$ \\
\hline & & Medium (13-15) & $41(68.33)$ & $31(51.67)$ \\
\hline & & High (16-18) & $09(15.00)$ & $15(25.00)$ \\
\hline \multirow[t]{3}{*}{9.} & \multirow{3}{*}{$\begin{array}{l}\text { Scientific } \\
\text { orientation }\end{array}$} & Low (11-13) & $06(10.00)$ & $05(8.33)$ \\
\hline & & Medium (14-15) & $22(36.67)$ & $40(66.67)$ \\
\hline & & High (16-18) & $32(53.33)$ & $15(25.00)$ \\
\hline
\end{tabular}


Table.2 perception of the Respondents about ZBNF

\begin{tabular}{|c|c|c|c|c|c|c|c|}
\hline \multirow{2}{*}{$\begin{array}{l}\text { Sl. } \\
\text { No. }\end{array}$} & \multirow{2}{*}{ Statement } & \multicolumn{3}{|c|}{ Beneficiaries [F (\%)] } & \multicolumn{3}{|c|}{ Non-Beneficiaries [F (\%)] } \\
\hline & & A & UD & DA & A & UD & DA \\
\hline 1. & $\begin{array}{l}\text { ZBNF is relatively } \\
\text { Advantageous over } \\
\text { chemical farming. }\end{array}$ & $\begin{array}{c}57 \\
(95)\end{array}$ & $\begin{array}{c}3 \\
(5)\end{array}$ & 00 & $\begin{array}{c}17 \\
(28.33)\end{array}$ & $\begin{array}{c}24 \\
(40)\end{array}$ & $\begin{array}{c}19 \\
(31.67)\end{array}$ \\
\hline 2. & $\begin{array}{l}\text { ZBNF gives more net } \\
\text { returns. }\end{array}$ & $\begin{array}{c}46 \\
(76.66)\end{array}$ & $\begin{array}{c}11 \\
(18.33)\end{array}$ & $\begin{array}{l}3 \\
(5)\end{array}$ & $\begin{array}{c}5 \\
(8.33)\end{array}$ & $\begin{array}{c}25 \\
(41.66)\end{array}$ & $\begin{array}{c}30 \\
(\mathbf{5 0})\end{array}$ \\
\hline 3. & $\begin{array}{l}\text { ZBNF reduces cost of } \\
\text { cultivation. }\end{array}$ & $\begin{array}{c}37 \\
(61.66)\end{array}$ & $\begin{array}{c}18 \\
(30)\end{array}$ & $\begin{array}{c}5 \\
(8.33)\end{array}$ & $\begin{array}{c}10 \\
(16.66)\end{array}$ & $\begin{array}{c}31 \\
(51.67)\end{array}$ & $\begin{array}{c}19 \\
(31.66)\end{array}$ \\
\hline 4. & $\begin{array}{l}\text { ZBNF is feasible to adopt } \\
\text { in present farming } \\
\text { situation. }\end{array}$ & $\begin{array}{c}55 \\
(91.66)\end{array}$ & $\begin{array}{c}5 \\
(8.33)\end{array}$ & 00 & $\begin{array}{c}16 \\
(26.66)\end{array}$ & $\begin{array}{c}18 \\
(30)\end{array}$ & $\begin{array}{c}26 \\
(43.33)\end{array}$ \\
\hline 5. & ZBNF is complex to adopt. & $\begin{array}{c}16 \\
(26.67)\end{array}$ & $\begin{array}{c}20 \\
(33.33)\end{array}$ & $\begin{array}{c}24 \\
(40)\end{array}$ & $\begin{array}{c}19 \\
(31.66)\end{array}$ & 00 & $\begin{array}{c}41 \\
(68.33)\end{array}$ \\
\hline 6. & ZBNF enriches the soil. & $\begin{array}{c}58 \\
(96.66)\end{array}$ & $\begin{array}{c}02 \\
(3.33)\end{array}$ & 00 & $\begin{array}{c}21 \\
(35)\end{array}$ & $\begin{array}{c}35 \\
(58.33)\end{array}$ & $\begin{array}{c}4 \\
(6.66)\end{array}$ \\
\hline 7. & $\begin{array}{l}\text { ZBNF gives sustainable } \\
\text { yield. }\end{array}$ & $\begin{array}{c}52 \\
(82.66)\end{array}$ & $\begin{array}{c}7 \\
(11.67)\end{array}$ & $\begin{array}{c}1 \\
(1.66)\end{array}$ & $\begin{array}{c}16 \\
(26.67)\end{array}$ & $\begin{array}{c}42 \\
(70.00)\end{array}$ & $\begin{array}{c}4 \\
(6.66)\end{array}$ \\
\hline 8. & $\begin{array}{l}\text { ZBNF facilitates natural } \\
\text { enemies' population. }\end{array}$ & $\begin{array}{c}52 \\
(86.67)\end{array}$ & $\begin{array}{c}6 \\
(10)\end{array}$ & $\begin{array}{c}2 \\
(3.33)\end{array}$ & $\begin{array}{c}15 \\
(25)\end{array}$ & $\begin{array}{c}41 \\
(68.33)\end{array}$ & $\begin{array}{c}4 \\
(6.67)\end{array}$ \\
\hline 9. & $\begin{array}{l}\text { ZBNF is difficult to } \\
\text { practice. }\end{array}$ & $\begin{array}{c}15 \\
(25)\end{array}$ & $\begin{array}{c}15 \\
(25)\end{array}$ & $\begin{array}{c}30 \\
(50)\end{array}$ & $\begin{array}{c}32 \\
(53.33)\end{array}$ & $\begin{array}{c}26 \\
(43.33)\end{array}$ & $\begin{array}{c}2 \\
(\mathbf{3 . 3 3})\end{array}$ \\
\hline 10. & $\begin{array}{l}\text { ZBNF produces quality } \\
\text { production. }\end{array}$ & $\begin{array}{c}55 \\
(91.66)\end{array}$ & $\begin{array}{c}5 \\
(8.33)\end{array}$ & 00 & $\begin{array}{c}15 \\
(25)\end{array}$ & $\begin{array}{c}37 \\
(61.66)\end{array}$ & $\begin{array}{c}\mathbf{8} \\
(\mathbf{1 3 . 3 3})\end{array}$ \\
\hline 11. & $\begin{array}{l}\text { ZBNF increases } \\
\text { microorganisms and } \\
\text { Earthworms in soil. }\end{array}$ & $\begin{array}{c}56 \\
(93.330\end{array}$ & $\begin{array}{c}4 \\
(6.67)\end{array}$ & 00 & $\begin{array}{c}18 \\
(30)\end{array}$ & $\begin{array}{c}37 \\
(61.66)\end{array}$ & $\begin{array}{c}5 \\
(8.33)\end{array}$ \\
\hline 12. & $\begin{array}{l}\text { ZBNF is possible on large } \\
\text { scale. }\end{array}$ & $\begin{array}{c}11 \\
(18.33)\end{array}$ & $\begin{array}{c}21 \\
(35)\end{array}$ & $\begin{array}{c}27 \\
(45)\end{array}$ & $\begin{array}{c}3 \\
(5)\end{array}$ & $\begin{array}{c}35 \\
(58.33)\end{array}$ & $\begin{array}{c}22 \\
(36.66)\end{array}$ \\
\hline 13. & $\begin{array}{l}\text { Preparation of asthras is } \\
\text { difficult. }\end{array}$ & $\begin{array}{c}12 \\
(20)\end{array}$ & $\begin{array}{c}9 \\
(15)\end{array}$ & $\begin{array}{c}39 \\
(65)\end{array}$ & $\begin{array}{c}32 \\
(53.33)\end{array}$ & $\begin{array}{c}28 \\
(46.67)\end{array}$ & $\mathbf{0 0}$ \\
\hline 14. & $\begin{array}{l}\text { Weed management is } \\
\text { difficult in ZBNF. }\end{array}$ & $\begin{array}{c}1 \\
(1.66)\end{array}$ & $\begin{array}{c}12 \\
(20)\end{array}$ & $\begin{array}{c}47 \\
(78.33)\end{array}$ & $\begin{array}{c}36 \\
(60)\end{array}$ & $\begin{array}{c}14 \\
(23.33)\end{array}$ & $\begin{array}{c}10 \\
(16.67)\end{array}$ \\
\hline 15. & $\begin{array}{l}\text { Availability of traditional } \\
\text { varieties seed is difficult. }\end{array}$ & $\begin{array}{c}50 \\
(83.33)\end{array}$ & $\begin{array}{c}4 \\
(6.67)\end{array}$ & $\begin{array}{c}6 \\
(10)\end{array}$ & $\begin{array}{c}41 \\
(68.33)\end{array}$ & $\begin{array}{c}9 \\
(15)\end{array}$ & $\begin{array}{c}10 \\
(16.67)\end{array}$ \\
\hline 16. & $\begin{array}{l}\text { Purchasing and } \\
\text { maintaining of traditional } \\
\text { Cows is difficult. }\end{array}$ & $\begin{array}{c}33 \\
(\mathbf{5 5})\end{array}$ & $\begin{array}{c}9 \\
(15)\end{array}$ & $\begin{array}{c}18 \\
(30)\end{array}$ & $\begin{array}{c}\text { 30 } \\
(\mathbf{5 0})\end{array}$ & $\begin{array}{c}28 \\
(26.67)\end{array}$ & $\begin{array}{c}2 \\
(3.33)\end{array}$ \\
\hline
\end{tabular}

[Fully correct (F.P.), partially correct (P.P.), not correct (N.P.) Frequency (F), p e r centage (P \%).] 
Table.3 Overall Distribution of Beneficiaries Respondents according to their perception of Respondents about ZBNF

\begin{tabular}{|c|c|c|c|}
\hline Sl. No. & $\begin{array}{c}\text { Perception of respondents } \\
\text { about ZBNF }\end{array}$ & \multicolumn{2}{|c|}{ Beneficiaries } \\
\cline { 3 - 4 } & Frequency (F) & percentage (\%) \\
\hline $\mathbf{1}$ & Low (24-31) & 02 & $\mathbf{3 . 3 3}$ \\
\hline $\mathbf{2}$ & Medium (32-38) & 25 & $\mathbf{4 1 . 6 7}$ \\
\hline $\mathbf{3}$ & High (39-46) & 33 & $\mathbf{5 5 . 0 0}$ \\
\hline & Total & $\mathbf{6 0}$ & $\mathbf{1 0 0 . 0 0}$ \\
\hline
\end{tabular}

Table.4 Overall Distribution of Non-Beneficiaries Respondents according to their perception of Respondents about ZBNF

\begin{tabular}{|c|c|c|c|}
\hline Sl. No. & $\begin{array}{c}\text { Perception of respondents } \\
\text { about ZBNF }\end{array}$ & \multicolumn{2}{|c|}{ Non- Beneficiaries } \\
\cline { 3 - 4 } & Frequency ( F ) & percentage (\%) \\
\hline $\mathbf{1}$ & Low (28-34) & 31 & $\mathbf{5 1 . 6 7}$ \\
\hline $\mathbf{2}$ & Medium (35-40) & 20 & $\mathbf{3 3 . 3 3}$ \\
\hline $\mathbf{3}$ & High (41-46) & 09 & $\mathbf{1 5 . 0 0}$ \\
\hline & Total & $\mathbf{6 0}$ & $\mathbf{1 0 0 . 0 0}$ \\
\hline
\end{tabular}

Table.5 Coefficient of Correlation between selected independent variables with p e r ception level of the respondents towards ZBNF

$\mathrm{n}=120$.

\begin{tabular}{|c|c|c|c|}
\hline \multirow[t]{2}{*}{ Sl.no. } & \multirow[t]{2}{*}{ Characteristics } & \multicolumn{2}{|c|}{ 'r' value } \\
\hline & & Beneficiaries & Non-Beneficiaries \\
\hline 1. & Age & $0.082 \mathrm{NS}$ & $-0.220 \mathrm{NS}$ \\
\hline 2. & Education & $-0.998 *$ & $0.950 *$ \\
\hline 3. & Family size & $-0.974 *$ & $0.951 *$ \\
\hline 4. & Annual income & $-0.936^{*}$ & 0.993* \\
\hline 5. & Land holding & $0.327 * *$ & 0.993* \\
\hline 6. & Mass Media Exposure & $0.800 *$ & $0.901 *$ \\
\hline 7. & Extension Participation & $0.893^{*}$ & $0.814 *$ \\
\hline 8. & Extension contacts & $0.926^{*}$ & $0.945 *$ \\
\hline 9. & Risk orientation & $0.938 *$ & $0.865^{*}$ \\
\hline 10. & Scientific orientation & 0.938* & $0.851 *$ \\
\hline
\end{tabular}

* Significant at $1 \%$ level of probability

** Significant at $5 \%$ level of probability NS = Non-Significant 
Fig.1 perception of farmers on Zero Budget Natural Farming

- BENEFICIARIES

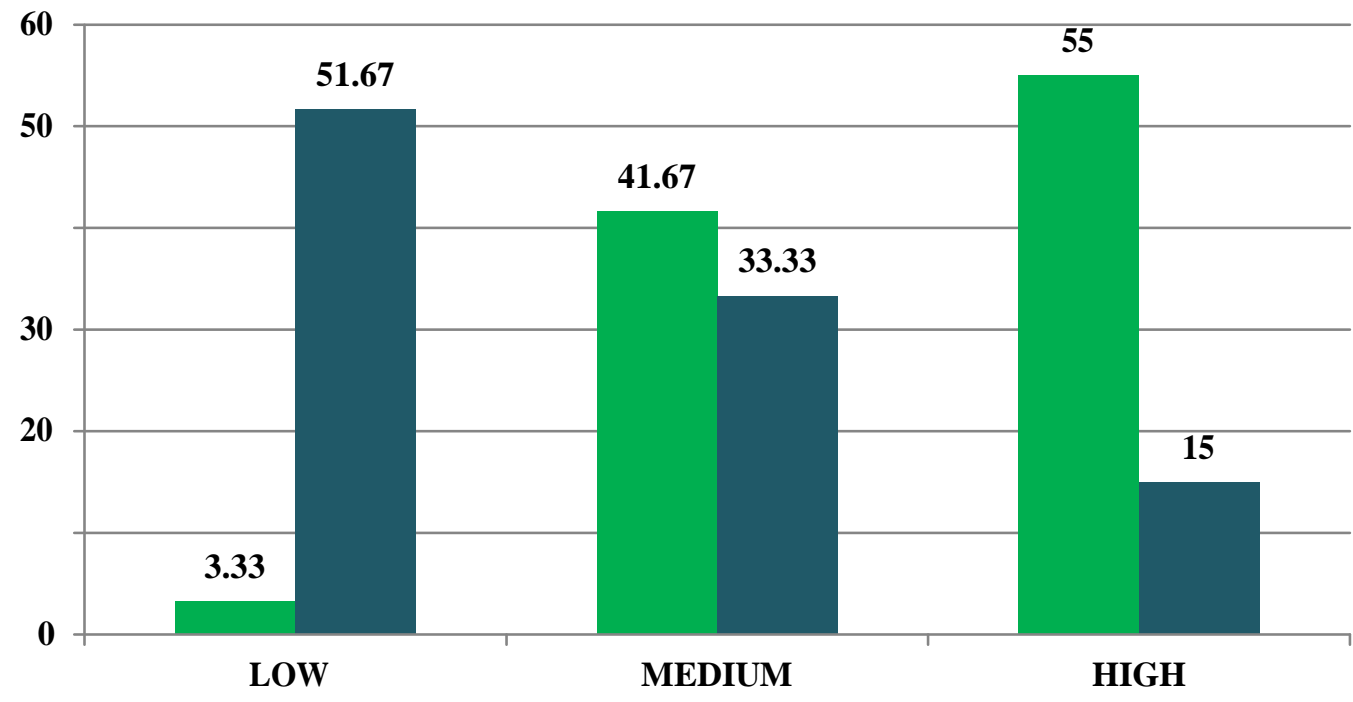

- NON BENEFICIARIES

\section{References}

1. Sarada, O. and Kumar, G. V. S. (2018): perception of the Farmers on Zero Budget Natural Farming in Prakasam District of Andhra Pradesh. The J. Res. PJTSAU, 46(1): 34-38.

2. Sivaraj, P., Philip, H. and Geetha Lakshmi, V. 2017. Climate Change Impact on Socio- Economics Status and Communication Pattern of the Paddy Farmers of Tamil Nadu, India. International journal of Current Microbiology and Applied Sciences. 6(6): 550-557.

3. Parganiha, O. 2016. Farmer's perception about Climate Change and its Impact on Agriculture and Allied Activities in Chhattisgarh Plains. Ph.D. (Agri.) Thesis. University of Indira Gandhi Krishi Vishwa Vidyalaya, Raipur, India.

4. Ansari, M. A., Joshi, S. and Raghauvanshi, R. 2018. Understanding
Farmers perceptions about Climate Change: a study in a North Indian State. Advances in Agriculture and Environmental Science. 1(2): 85-89.

5. Dave, A. A. 2017. A study on Farmers' perception towards Organic Input in Selected District of Gujarat, B.Sc.(Forestry) Thesis. International AgriBusiness Management Institute, Anand Agricultural University, Anand.

6. Priya, N. K. and Naidu, S.M.M. (2019), Reddy, B.G. (2019). Potential and Constraints of Zero Budget Natural Farming (ZBNF): A Study of Andhra Pradesh. Indian Journal of Agricultural Economics.74 (3).

7. Kumar N. (2012). Subash Palekar's Zero Budget No till Rice Farming.

8. Khadse, A., Rosset, P. M. (2019). Zero Budget Natural Farming in India-from inception to institutionalization. Agroecology and Sustainable Food Systems, 43 (7-8), 1-24. 


\section{How to cite this article:}

Kuramdasu Vijaya Saradhi, Jahanara and Harihara Tripathy. 2021. Perception of Zero Budget Natural Farming in Visakhapatnam District of Andhra Pradesh, India. Int.J.Curr.Microbiol.App.Sci. 10(08): 736-744. doi: https://doi.org/10.20546/ijcmas.2021.1008.082 